\title{
Malignant Cervical Soft Tissue Neoplasm
}

National Cancer Institute

\section{Source}

National Cancer Institute. Malignant Cervical Soft Tissue Neoplasm. NCI Thesaurus.

Code C128054.

A rare malignant mesenchymal neoplasm that arises from the cervix. 